\title{
"Does Inflation Targeting Framework Make a Significant Difference in Lowering Price Level?" What is Its Implication to Indonesia's Inflation Rate?
}

\author{
Faisal Rachman ${ }^{a,+}$ \\ ${ }^{a}$ Master Degree in Public Policy, Lee Kuan Yew School of Public Policy, National University of Singapore
}

\begin{abstract}
In the last two decades many countries have been starting to employ Inflation Targeting Framework (ITF) as their main monetary policy framework. This is done to achieve an objective of anchoring public expectation on inflation which in the end will steer the price level movement towards ITF's ultimate target of relatively low and stable inflation rate. By conducting Difference-in-Difference method on panel data consisting of 5 countries implementing ITF since 2001 and 21 selected non-ITF countries for period 1990-2010, it is statistically proved that ITF adoption has a significant effect on inflation. In case of Indonesia, through Structural Break approach, the implementation of ITF since 2005 is also proved able to lower and stabilize inflation rate.
\end{abstract}

Keywords: Inflation; Inflation Targeting; Monetary Policy; informasi terbaru; Structural Break;

\begin{abstract}
Abstrak
Dalam dua dekade terakhir ini banyak negara yang telah mulai menggunakan Inflation Targeting Framework (ITF) sebagai kerangka utama kebijakan moneter mereka. Hal ini dilakukan guna mencapai tujuan pengendalian ekspektasi publik yang pada akhirnya akan mengendalikan pergerakan tingkat harga relatif rendah and stabil. Dengan menggunakan metode Difference-in-Difference pada data panel, yang terdiri dari 5 negara yang telah mengimplementasikan ITF sejak tahun 2001 dan 21 negara bukan pengguna ITF, untuk periode 1990-2010, disimpulkan bahwa ITF memiliki dampak signifikan pada tingkat inflasi. Untuk kasus Indonesia yang telah mengimplementasikan ITF sejak tahun 2005, melalui metode Structural Break disimpulkan hasil yang sama, yaitu tingkatan harga yang rendah dan stabil.
\end{abstract}

Kata kunci: Inflasi; Target Inflasi; Kebijakan Moneter

JEL classifications: E310; E520

\section{Introduction}

\subsection{Background of Study}

A rise in overall level of prices of goods and services in one country over one period often give a bad signal to the economy. This is due to its effect in distracting patterns of savings and investments, impairing business environments, increasing input price of productions, bringing down purchasing powers (lower real income) and giving un-

\footnotetext{
+Corresponding Address: Jln. Hateup No. 22 Bantarjati, Bogor. E-mail: faisal.rachman.feui@gmail.com.
}

certainty to a society leading to inhibition for the economy to grow. Additionally, it also may plunge the competitiveness of a country in the global environment since higher domestic price level will weaken the real interest rate and therefore domestic currency. In economic term, this phenomenon is commonly recognized as inflation.

Generally speaking, inflation is something that cannot be hindered, but the central bank or monetary authority of a nation can manage or control it through monetary policy. The instruments of monetary policy, which are usually implemented in controlling price level, are interest rate and size of money supply adjustments. This conservative 
monetary policy is unfortunately still not quite effective enough in managing inflation rate, especially in this globalization era in which global economy is highly integrated and is very often experiencing external shocks, such as a recent series of economic crises.

\subsection{Inflation Targeting Framework}

In the last two decades, many countries have started to implement a new approach of managing inflation rate called Inflation Targeting Framework (ITF) as the main framework of their monetary policy. There is no one universal description of what ITF really is. However, in general it can be defined as a framework of monetary policy which has an official estimated target for the level of inflation in specific time horizon in one country, sets a relatively low and stable inflation rate as a final target and a primary long-run goal and attempts to steer actual inflation rate toward the estimated target (Bernanke et al. 1999, p. 4).

In implementing ITF, two preliminary requirements need to be fulfilled. The requirements are first, ability of the central bank or the monetary authority to conduct monetary policy with some degrees of independence meaning that there is a certain degree of freedom from government influence or intervention and second, willingness of central bank or monetary authority to only target inflation rate and not other indicators, such as wage, employment or exchange rate (Jahan 2012).

Comparing ITF to the conservative monetary policy framework, there are four elements making it novel and different from the conservative one (Mishkin 2004, p. 16). The elements are:

1. Establishing an explicit mandate to pursue price stability as the primary objective of monetary policy and quantitative target of the inflation rate for a specific period.

2. Announcing the inflation target clearly and unambiguously to the public in order to anchor public expectation on the inflation level.

3. Emphasizing on accountability and hightransparency of policy performance in achieving the primary objective.

4. Implementing inflation forecasting approach and forward-looking operating procedure, which use several indicators containing future inflation information.

In operating procedure, ITF allows a central bank or monetary authority to adopt some instruments or monetary tools, such as open market operation, minimum reserve requirement and discount rate policy in anchoring the price level to the target. One important thing that should be noticed is that despite various instruments that countries' monetary authorities may use during the implementation, there is only one ultimate objective of ITF, which is anchoring inflation rate to be relatively low and stable. It thus still can be counted as one wholly set of ITF policy.

There are a lot of reasons why this framework is starting to be popularly employed by various countries. These reasons are associated with benefits that come up from ITF itself. First, achieving price stability means that the monetary policy is successful in giving contribution on economic growth by avoiding boom and bust economic condition and in enhancing purchasing power of society (Debelle et al. 1998). Second, due to its simplicity and clarity of an explicit numerical target, this framework can lead markets to lower their expectation of inflation, which later can really reduce the inflation rate (Mishkin 2007, pp. 402-411). Last but not least, ITF also can give positive credibility to the central bank or monetary authority through its transparency and accountability (Mishkin 2007, pp. 402-411).

Another reason of why countries adopt this framework is also due to the success of ITF compared to other monetary approaches in terms of price stabilization. Monetary policy regime like monetary base targeting has been proven to be failed in controlling price fluctuations. It also can make demand for money become unstable and is ineffective in reducing the costs of inflation (Jahan 2012). Indeed, inflation targeting can overcome inflation costs such as lower investment, loss in international competitiveness and reduced value of savings, better than other monetary frameworks.

\subsection{Issue Addressed in This Study}

First adopted by New Zealand in the year 1990, nowadays ITF has already been implemented in 28 countries (see Table 1) and has shown 
Table 1: The List of the Countries Adopting ITF and First-Year Implementation

\begin{tabular}{ll}
\hline Industrial Countries & Emerging Market Countries \\
\hline New Zealand (1990), Canada (1991), United Kingdom (1992), & Czech Republic (1997), Israel (1997), Poland (1998), Brazil \\
Australia (1993), Sweden (1993), Iceland (2001) and Norway & (1999), Chile (1999), Columbia (1999), South Africa (2000), \\
(2001) & Thailand (2000), Hungary (2001), Mexico (2001), South Korea \\
& (2001), Peru (2002), Philippines (2002), Guatemala (2005), In- \\
& donesia (2005), Romania (2005), Serbia (2006), Turkey (2006), \\
& Armenia (2006), Ghana (2007) and Albania (2009) \\
\hline Source: IMF &
\end{tabular}

great attainment in controlling price level (Jahan 2012). In addition, according to the International Monetary Fund (IMF), from statistical data, countries implementing ITF have successfully escaped from numerous economic crises and have experienced better economic performances (Roger 2010). Based on that, a number of central banks including the European Central Bank, the U.S. Federal Reserve, the Bank of Japan and the Swiss National Bank have been ready to fully adopt ITF (Roger 2010). One of the latest findings from a study by the IMF in 2005 has concluded that adoption of the ITF can reduce $4.8 \%$ of the average inflation rate of selected emerging market and industrial countries compared to other monetary policy regimes between the year of 1990 and 2004 (IMF 2005).

In the case of Indonesia, since July 2005, the central bank of Indonesia, Bank Indonesia, has been employing ITF with a free floating exchange rate and setting the new nominal anchor, which is price index, after abandoning the crawling band exchange rate system in 1997 due to the Asian Financial Crisis 1997/1998 and replacing base money targeting as the framework of its monetary policy (Bank Indonesia n.d.). It has been proven that managed exchange rate system fails to help the economy in stabilizing the price level since it makes money supply difficult to control and unintentionally pushes the economy to import inflation from another country, to which the exchange rate is pegged.

Under the Law of Bank Indonesia, inflation target is set together by Bank Indonesia and the Indonesian government by issuing a Memorandum of Understanding between them. The latest is the Decree of the Minister of Finance No. 66/PMK.011/2012, which set inflation target in year 2013, 2014 and 2015 to be $4.5 \%, 4.5 \%$ and $4 \%$ respectively with $\uparrow 1 \%$ deviation (Bank Indonesia n.d.). Unfortu- nately, there are still not many studies scrutinizing the significance of ITF implementation in Indonesia on the price level.

\subsection{Objective of Study}

This study is trying to conduct impact evaluation on ITF and to assess it in order to see whether in general it still could significantly reduce inflation rate (causal effect of ITF on inflation rate) in more recent years including the period of the Global Economic Crisis. Furthermore, this study will also attempt to estimate the implication of ITF in Indonesia's economy, specifically to see whether it has a significant result or not.

\subsection{Research Questions}

There are three main questions that will be addressed in this study. The questions are (1) Is ITF a better framework for monetary policy in keeping the price level stable and low?; (2) How significant can ITF reduce inflation rate?; and (3) In the case of Indonesia, does ITF really work in stabilizing price level?

\section{Literature Review}

The following are some literatures on the influence of ITF employment on the price level in some economies. Methods of analysis being used are different from one literature to another, comprehending simple method like descriptive analysis and advanced method like econometric modeling. Interestingly, the conclusion of one literature is not always consistent with the other, suggesting that 
the adoption of the ITF as monetary framework is not always able to bring down inflation rate.

Mishkin (2004) studied the effect of the ITF on the inflation rate in two selected emerging countries, namely Chile and Brazil. Using descriptive analysis, he found that after the adoption of the ITF in the year 1999, Chile has been successfully lowering the inflation rate from previously above $20 \%$ in the year 1991 to around $2 \%$ in year 2002 . The output growth also indicated an increasing trend after the implementation. This incredible result was mainly caused by the development of a monetary institution, supporting the inflation-targeting regime. The development included the independence of the central bank as one of ITF prerequisites, which later increased the central bank's credibility in managing price level.

Brazil also adopted ITF in the year 1999. Unfortunately, the implementation was not built on a strong foundation of monetary reform. Independence of Brazil's central bank, according to the study, was still questionable at that time. Despite all of that, ITF implementation surprisingly seemed to show a good result. Inflation rate dropped from $8.9 \%$ in the year 1999 to $7.7 \%$ in the year 2001. Even though showing a decreasing trend, the actual inflation rate of year 2001 was exceeding the 4\% inflation target with $2 \%$ tolerance range, demonstrating the weakness of some aspect of the institutional framework for monetary policy. Based on those findings, Mishkin concluded that the ITF is still feasible for emerging countries, where political and economic factors are prone to be more volatile, in keeping inflation rate relatively low and stable.

Different with what Mishkin has concluded, through several econometric approaches (Instrumental Variables method, assumptions about heteroscedasticity and Panel Fixed Effects model) in estimating the effect of ITF on inflation, Willard (2006) concluded that the effect of the implementation is generally small and insignificant. Dataset being used in this study was quarterly inflation rate dataset from Q1 1985 to Q3 2002 for OECD country members (Australia, Austria, Belgium, Canada, Denmark, Finland, France, Germany, Greece, Ireland, Italy, Japan, Luxembourg, Netherlands, New Zealand, Norway, Portugal, Spain, Sweden, Switzerland, the United Kingdom, and the United States). A study conducted by Lin and Ye (2007) found similar result with what Luke has concluded, asserting that the ITF is not really working in industrial countries. Using dataset for 22 major industrial countries, with 7 out of them are countries adopting ITF (Australia, Canada, Finland, New Zealand, Spain, Sweden and the United Kingdom), for period of year 1985 to year 1999 on Propensity Score Matching (PSM) method, they concluded that ITF has no significant effect on inflation rate.

A study conducted by Gemayel, Jahan and Peter (2011) however supported the result of Mishkin's study. Applying Difference-in-Difference (DiD), PSM and panel estimations including Generalized Methods of Moments (GMM) methods on macroeconomic dataset of 36 (thirty-six) lowincome countries, covering ITF and non-ITF countries, the study stated that ITF appeared to be associated with lower inflation and inflation volatility. Inflation rate on average has fallen by $1.96 \%$ to $2 \%$ after the ITF has been employed. Daboussi (2014) also supported this finding. Applying the differences-in-differences approach on panel data of 53 developing countries, of which 20 of them have adopted IT by the end of year 2007, the author confirmed that ITF adoption significantly contributed in making inflation rate relatively low. Average inflation rate of ITF countries decreased by around $1.12 \%$, after the implementation of the ITF.

By comparing those all mentioned literatures, it may indicate that there is a possibility for ITF policy to not have significant impact on the price level in industrial countries. However, this finding on the implementation of ITF in developed countries cannot be fully relied upon as there is another study finding opposite conclusion. Inconsistent with what Luke and, Lin and Ye believed, Brito (2011) in his study argued the notion saying that the ITF has no impact in lowering inflation rate in industrial countries. Using Dynamic Panel regressions on inflation dataset for year 1984 to 1999 of 22 major OECD economies, divided into a treatment group of 7 ITF countries (Australia, Canada, Finland, New Zealand, Spain, Sweden and United Kingdom) and a control group of 15 non-ITF countries (Austria, Belgium, Denmark, France, Germany, Greece, Iceland, Ireland, Italy, Japan, Netherlands, Norway, Portugal, Switzerland and the United States), the literature concluded that ITF is a good framework in managing inflation rate to be relatively low and stable in developed economies. Brito suggested that dynamic panel approach is a better method in controlling time variation and countries' specifici- 
ties than PSM method (approach used in Lin and Ye's) since the approach is able to exploit time and country dimensions to isolate the exclusive effect of ITF regime on inflation rate from other economic factors which may influence it.

\section{Method}

This study clusters the analysis into two parts. First, the study estimates the causal effect of ITF implementation on the price level in a more general analysis. Here the study exerts selected countries applying ITF and countries not applying in a certain period of time to be used in the impact evaluation analysis of Difference-in-Differences (DiD) method. Second, the study inspects whether there is a significant change in the pattern of price level in Indonesia after the implementation of the ITF by conducting a Chow test on a distributed-lag model.

\subsection{Data}

For impact evaluation analysis, not all countries adopting the ITF will be subjects of the study. Only 5 countries starting to implement ITF in year 2001 and 21 selected non-ITF countries will be included in the dataset. In addition, the range of the data will be limited from the year 1990 to 2010 due to data availability. This is done to make the analysis clearer, to avoid bias problem from class imbalance since the study is trying to compare pre- and post-period after the adoption, and to balance the dataset. Moreover, it is also done in order to satisfy Stable Unit Treatment Value Assumption (SUTVA) condition, aiming to make sure that there is no variation in policy intervention in the scope of the study. The datasets are yearly data and collected from the International Monetary Fund's World Economic Outlook Database, World Bank's World Development Indicator and KOF Swiss Economic Institute's dataset.

In order to examine the change in the pattern of price movements after ITF application in Indonesia, the study exerts monthly year-over-year (y.o.y.) basis inflation rate using the percentage change in Consumer Price Index (CPI) dataset from year 1990 to 2014. The dataset is collected from the In- ternational Monetary Fund's International Financial Statistics.

\subsection{Impact Evaluation Methodology}

To see the effect of ITF implementation on reducing the inflation rate, this study uses impact evaluation by comparing countries which are employing ITF and which are not in terms of their inflation rate in the period of the year 1990 to 2010 . Therefore, the study shall use "before and after" approach for setting up groups and the ITF adoption starting the year 2001 as a policy intervention. Countries employing ITF starting in year 2001 will be classified as treatment group, and countries not employing ITF will be classified as a control group (see Table 2). Countries in the control group are selected due to their absence on ITF adoption over the period of 1990-2010, representativeness of both developed and developing countries in the group, and data availability.

Based on the above, a Difference-in-Differences (DiD) method will be applied in estimating the effect of ITF implementation on price level of countries in the treatment group by comparing the price level of the two groups. Hence, the treatment variable (noted with "ITF") will be a dummy variable explaining whether a country implementing ITF or not, and the outcome variable is the inflation rate (see Table 3).

To avoid omitted variable bias problem, other covariates which can independently affect outcome variable such as broad money growth, government fiscal balance, five-year central bank governor turnover rate (as an inverse proxy of central bank independence), trade to GDP ratio as a measure of country's openness to trade, two dummy variables for crisis periods and a dummy variable for country category are used as control variables (Kasseeah, Weng and Mohepuut 2011, pp. 325332) (see Table 4).

In conducting the DiD method for this study, there are several crucial concepts that must be noticed. The concepts are (Stock and Watson 2012, pp. 532-535):

1. Time frame on the period before and after the ITF is introduced should be clearly defined. In this study, pre-period will be the year 1990- 
Table 2: Treatment and Control Groups

\begin{tabular}{ll}
\hline Group & Countries \\
\hline Treatment Group & Hungary, Iceland, Mexico, Norway and South Korea. \\
Control Group & $\begin{array}{l}\text { Argentina, Bangladesh, China, Ecuador, Egypt, France, Ger- } \\
\text { many, Hong Kong, India, Japan, Malaysia, Morocco, Pak- } \\
\text { istan, Panama, Russia, Saudi Arabia, Singapore, Switzerland, } \\
\text { Uruguay, USA and Venezuela }\end{array}$ \\
\hline
\end{tabular}

Table 3: Outcome and Treatment Variables

\begin{tabular}{ll}
\hline Variable & Description \\
\hline Inflation Rate $(\%)$ & $\begin{array}{l}\text { It is the annual percentage change or movement in a price index } \\
\text { based on the Consumer Price Index (CPI). }\end{array}$ \\
$\begin{array}{ll}\text { ITF (implementing }=1, \text { or otherwise = 0) (Treatment Variable) } \\
\text { It is a dummy variable, which equals to } 1 \text { if a country implements } \\
\text { ITF and equals to } 0 \text { if a country does not implement ITF. }\end{array}$ & $\begin{array}{l}\text { The hypothesis of a relationship between this variable and in- } \\
\text { flation rate as outcome variable is that there is a lower price } \\
\text { level for countries in the treatment group compared to the con- } \\
\text { trol group. In other words, a country implementing ITF will have } \\
\text { lower inflation rate compared to a non-ITF country. }\end{array}$ \\
\hline
\end{tabular}

2000 and post-period will be the year 20012010.

2. The only distinction between treatment and control groups is that the treatment group is the one exposed to ITF and control group is not. Hence, they will experience same external conditions except ITF as policy intervention.

3. The DiD method calculates two measures of change over the time period in which one for the treatment group and one for the control group. Here, consideration of change over time (from pre- to post-period), which happens in both groups, is very essential to measure. This is called natural change due to timevarying factors. Based on that, differences in treatment group will be a measure of natural change and a change due to the introduction of the ITF. Dissociate those natural changes from the change resulting from the ITF, will give us the sole effect of ITF employment on the inflation rate.

4. This method does not require averagely similar treatment and control groups before the ITF is introduced, but it requires equal trend during pre- period (time-invariant during preperiod) for both groups. It means that in the nonappearance of ITF policy, the difference between two groups moves in tandem, and if the later experience fluctuation, it is then attributable to the implementation of ITF. This concept is associated with the condition of same external factors exposing the two groups as already explained previously. In this study, inflation rate movements of the two groups are already compared and resulting similar trend for the period of 1990-2000 (see Figure 1).

Referring to the concept, the treatment variable alone cannot be used in explaining relationship between policy intervention and outcome variable. It is because it is not illustrating causal effect of the ITF on the inflation rate but rather only comparing the inflation rate between countries in treatment and control groups regardless of the time periods (before or after the introduction of ITF). So basically, the treatment variable alone fails to capture the pure effect of ITF after it is adopted (during post-period).

Besides that, the difference in inflation rate between treatment and control groups may exist because of natural changes within each group in preand post-periods due to time varying factor, not because of ITF. Therefore, the pure effect of the ITF on inflation rate must be separated from those natural changes.

In accordance to that, there are two additional vari- 
Table 4: Covariates

\begin{tabular}{|c|c|c|}
\hline Variable & Hypothesis & Description \\
\hline Broad Money Growth (\%) & + & $\begin{array}{l}\text { If the money supply is increasing in the economy, it will } \\
\text { drop the value of money, which later will increase the } \\
\text { price level. In other words, if money growth increases, } \\
\text { inflation rate will go up. }\end{array}$ \\
\hline Government Fiscal Balance (\%) & - & $\begin{array}{l}\text { If a nation experiences from budget surplus, it means } \\
\text { that there is less government spending and more gov- } \\
\text { ernment revenue. In other words, the revenue from } \\
\text { taxes is greater than government expenditure. High tax } \\
\text { rate discourages economic activities (lowering aggre- } \\
\text { gate demand). Later, it will result in a lower inflation rate. }\end{array}$ \\
\hline Five-Year Central Bank Governor's turnover rate & + & $\begin{array}{l}\text { If rate of the central bank governor turnover is very high, } \\
\text { it can explain that the central bank is not independent } \\
\text { from the government. It also makes the monetary policy } \\
\text { implemented by the central bank is not credible. Thus, it } \\
\text { will cause uncertainty in the economy, which can raise } \\
\text { the inflation rate. }\end{array}$ \\
\hline Trade to GDP ratio (\%) & + & $\begin{array}{l}\text { This ratio measures the degree of openness of a coun- } \\
\text { try in international trade. The more open the economy of } \\
\text { a country is, the easier the economy can be influenced } \\
\text { by external factors coming from the international envi- } \\
\text { ronment. It means that a high degree of openness of } \\
\text { a country will result in a higher risk for a country to be } \\
\text { affected by imported inflation, which later can increase } \\
\text { domestic inflation rate. }\end{array}$ \\
\hline Crisis Period $($ crisis period $=1$, or otherwise $=0$ ) & $+/-$ & $\begin{array}{l}\text { During an economic crisis, a nation will experience over- } \\
\text { driving economy, which heats economic activities and in } \\
\text { consequence increases the price level. }\end{array}$ \\
\hline Asia Financial Crisis 1997/1998 & & $\begin{array}{l}\text { After the boom period, an economy will enter a reces- } \\
\text { sion period when all economic activities are starting to } \\
\text { slow-down, which in result will lead to deflation. }\end{array}$ \\
\hline \multicolumn{3}{|l|}{.Global Economic Crisis 2007-2009 } \\
\hline $\begin{array}{l}\text { Country Category (industrial country }=1 \text {, or emerging } \\
\text { market country }=0 \text { ) }\end{array}$ & - & $\begin{array}{l}\text { Industrial country is also known as an advanced econ- } \\
\text { omy. It means that its industrial sector can produce } \\
\text { goods more efficient compared to emerging market } \\
\text { country. Indeed, emerging market country is still suf- } \\
\text { fering from the high-cost economy condition in produc- } \\
\text { ing goods. So, price fluctuation in industrial countries } \\
\text { will tend to be more stable than the price fluctuation in } \\
\text { emerging market countries. }\end{array}$ \\
\hline
\end{tabular}




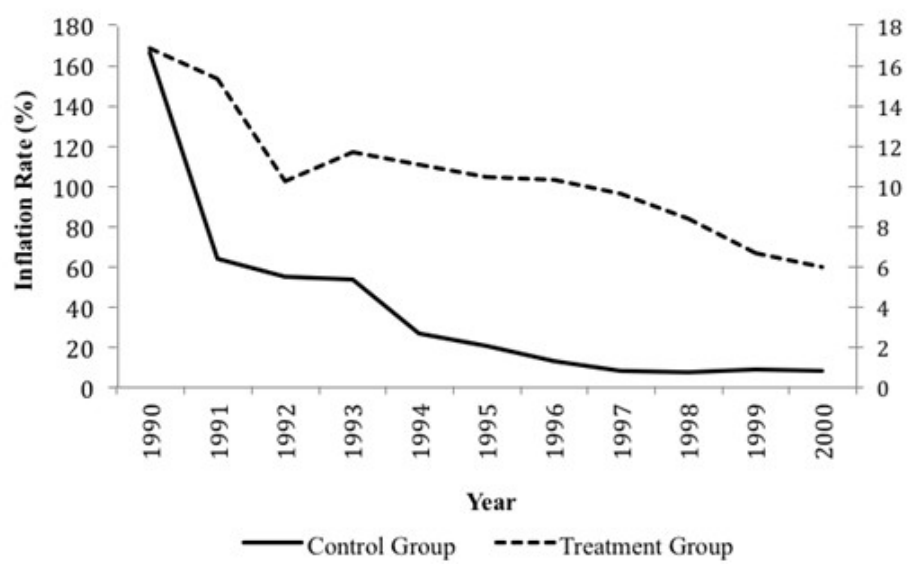

Figure 1: Inflation Rate Trends of Control and Treatment Groups (year 1990-2000) Source: IMF's World Economic Outlook Database (illustrated by author)

Table 5: Post-Period and Interaction Variable

\begin{tabular}{|c|c|}
\hline Variable & Description \\
\hline Post-Period (year 2001-2010 = 1, year 1990-2000 = 0) & $\begin{array}{l}\text { It is a dummy variable, which gives value of one for the period } \\
\text { after the ITF is employed. }\end{array}$ \\
\hline Interaction Variable & $\begin{array}{l}\text { It is multiplication between treatment variable and a dummy } \\
\text { variable for the post-period. Value of this variable will take one } \\
\text { only for countries in the treatment group in the post-treatment } \\
\text { period (year 2001-2010). }\end{array}$ \\
\hline (ITF $x$ Post-Period) & $\begin{array}{l}\text { The coefficient of this variable can expose the causal effect of } \\
\text { ITF implementation in the year } 2001 \text { up to } 2010 \text { on inflation rate } \\
\text { volatility, which interprets the pure effect of the ITF. Moreover, by } \\
\text { using interaction variable, natural change for each group from } \\
\text { the year } 1990 \text { to } 2010 \text { due to time-varying factor also can be } \\
\text { separated from the pure effect of the ITF. } \\
\text { Relationship hypothesis of this variable on outcome variable is } \\
\text { negative, meaning that ITF implementation since } 2001 \text { may re- } \\
\text { duce the inflation rate. }\end{array}$ \\
\hline
\end{tabular}


ables needed in conducting the DiD method. The variables are a dummy variable for post-period and interaction variable between treatment, and a dummy variable for the post-period, which can explain pure effect of ITF implementation since the year 2001 (see Table 5).

In general, DiD regression model can be written as:

$$
\begin{aligned}
Y_{i t} \equiv & \beta_{\mathbf{0}}+\beta_{1} X_{i t}+\beta_{\mathbf{2}} T_{i t}+\beta_{\mathbf{3}} X_{i t}+T_{i t} \\
& + \text { covariate(s) }+\varepsilon_{i t}
\end{aligned}
$$

Where,

$X_{i}$ : Treatment variable $(=1$ if treated, $=0$ if not treated).

$T_{i}$ : Time variable $(=1$ if post-treatment period, $=$ 0 if pre-treatment period).

$X_{i} \mathbf{\dagger} T_{i}$ : Interaction variable between treatment and time variables.

Covariates : Other independent variables, which can independently affect outcome variable.

$Y_{i}$ : Outcome variable.

$\varepsilon_{i}:$ Error term.

To test the causal effect between ITF as policy intervention on inflation rate, this study will use and compare three forms of the DiD regression model. The models are:

1. The DiD regression model without covariates.

2. The DiD regression model with covariates.

3. The DiD regression model with country fixed effect. This regression model can control unobserved characteristics for each country in the model. In this model, countries will be clustered into four classes, which are low-income economies, lower-middle-income economies, upper-middle-income economies and highincome economies, referring World Bank's grouping.

This impact analysis is nevertheless not totally free from some shortcomings. In general, there are four shortcomings that can be highlighted from this study. First, this study is only using countries starting to employ ITF since the year 2001 whereas there are many other countries implementing it before and after the year 2001. The reason behind why this study picks countries adopting ITF in the year 2001 is to make the treatment group consist of both industrial and emerging market countries. There are only 7 industrial countries up to now, which have employed ITF as their monetary framework and two out of them started implementing
ITF in year 2001. The other two industrial countries adopted ITF in the year 1993, while the rest three did it in the year 1990, 1991, and 1992. The year 1993 is not chosen because the first emerging market country started to implement ITF in the year 1997 (see Table 1 to get clearer information). Again, the representativeness of both industrial and emerging market countries in the treatment group is considered for this study. This may hence create problem of generalization (external validity issue) of the result since this analysis uses only 5 countries out of 28 countries adopting ITF.

Second, for deeper analysis, this study also cannot see which monetary instrument or tool inside ITF that is the most effectively used in reducing the inflation rate. The study only accounts for the capability of ITF in ensuring and anchoring the price level to the desired specific target. Third, the result also may suffer from possibility of confounding factor or unobserved characteristics problem since it uses country level data, and each country has its own unique economic, political and social characteristics, which sometimes cannot be easily compared or generalized to other countries, but can significantly affect inflation rate in that certain country.

Fourth, there is also a problem with the possibility of spillover and contaminated problem in this study, meaning that there is a possibility of countries in the control group affected, directly or indirectly, by ITF implementation of countries in the treatment group. For instance, if a non-ITF country is pegging its domestic currency to the currency of another country employing ITF, then non-ITF country is indirectly affected by effect resulting from ITF.

\subsection{Structural Break: Chow test on a Distributed-lag Model}

In order to scrutinize the effect of ITF implementation in Indonesia's inflation rate, this study exerts a Chow test on a distributed-lag model. The aim of this method is not to estimate the causal relationship between outcome variable and parameters, but rather to see a sudden change in that relationship within two periods of time. The test examines whether there exists a structural break in the pattern of inflation rate mostly caused by the adoption of the ITF. The structural break is prone to happen 
if there is a significant structural change in the relationship between the regressand and the regressors over period of time (Gujarati 2003, p. 273). If so, the ITF regime is believed to have altered the parameter values of the model and led to changes in the pattern of inflation rate in Indonesia.

Distributed-lag model is a regression model for time series data that includes not only current value but also the lagged value of its explanatory or dependent variable (Gujarati 2003, p. 656). In this case, the lag is used in explaining how inflation rate behavior in a present time could be influenced by past performance or historical information, which could change due to a certain policy, which in this case is ITF, leading to form a new expected inflation. Indeed, effects resulting from that alteration will not occur on the position of the inflation rate instantaneously, but rather distributed over subsequent time periods.

Since the data used are macroeconomic time series data, before running the regression model, there are at least two preconditions. First, the condition of stochastic process or a collection of random variables ordered in time must be held, which means the value of inflation rate in one specific time could be any number depending on economic condition or policy prevailing at that time, and shall be a particular realization of all possibilities (Gujarati 2003, pp. 796-797). Second, the inflation rate dataset must be stationary, which means the mean and variance are constant over time and the value of covariance between two-time periods depends only on the length of time lag but the actual time at which the covariance is computed (Gujarati 2003, pp. 797-798).

Stationarity in time series data is very essential because if it is not, the behavior reflected by the data, in this case is inflation rate dataset, for a particular time period will be different from that for other time periods. Therefore, it does not make much sense to generalize findings from the study to the entire time series. Non-stationary time series data cannot fully be trusted when forecasting the trend and behavior.

In order to test whether the inflation rate dataset used in this study are stationary, unit root test is conducted. The test begins by considering a firstorder autoregressive or $A R(1)$ with the inflation rate:

$$
Y_{t} \equiv \rho Y_{t \times 1}+u_{t}
$$

Where $Y_{t}$ is an inflation rate at time $t, Y_{t<1}$ is an inflation rate at time $t^{\&}<1$ and $u_{t}$ is a white noise error term, or an error term at time $t$, which is uncorrelated with the explanatory variables. The value of $\rho$ is in the range of $\xi_{-1} \uparrow \rho \uparrow$ I. If $\rho \equiv 1$, the model becomes a random walk model meaning that the model suffers from the unit root problem or nonstationary condition (Gujarati 2003, p.814). Hence, the notion of this model is to regress inflation rate on its lagged value then find out whether the estimated value of $\rho$ is equal to one.

Here, the Dickey-Fuller's first-difference test for examining unit root problem is performed. Subtracting both sides by $Y_{t \times 1}$ in the above equation, the equation becomes:

$$
\begin{gathered}
Y_{t} \equiv \rho Y_{t \times 1}+u_{t} \\
Y_{t} \& Y_{t \times 1} \equiv \rho Y_{t \times 1} \&<Y_{t \times 1}+u_{t} \\
\Delta Y_{t} \equiv \rho \&<1 Y_{t \times 1}+u_{t}
\end{gathered}
$$

If it is assumed that $\delta \equiv \rho \&<$, the model can be presented as:

$$
\Delta Y_{t} \equiv \delta Y_{t \times 1}+u_{t}
$$

Null hypothesis $\left(H_{0}\right)$ of this model is that $\delta \equiv 0$ or $\rho \equiv 1$, meaning that the time series data of inflation rate is not stationary (unit root problem exists), and its alternative hypothesis $(\mathrm{Ha})$ is $\delta \rightarrow 0$, meaning that inflation rate dataset is stationary. The reason why in alternative hypothesis $\delta$ is less than zero is that the value of $\rho$ must be less than one for stationarity (Gujarati 2003, p. 814).

After knowing that the inflation rate dataset is stationary, the study performs the Chow test on a distributed-lag model for two-time unit lagged. The model is:

$$
Y_{t} \equiv \alpha_{1}+\beta_{1} Y_{t \times 1}+\beta_{2} Y_{t \times 2}+u_{t}
$$

Where $Y_{t}$ is an inflation rate at time $t, Y_{t \times 1}$ is an inflation rate at time $t \&<1, Y_{t \times 2}$ is an inflation rate at time $t \&-2, \alpha_{1}$ is an intercept, $\beta$ is a parameter for each independent variable and ut is an error term. Since the study intends to investigate whether the adoption of ITF in Indonesia alters the trend of the inflation rate, the study divides the time series data into two periods by the time when the 
implementation took effect (July 2005 is the cut off). What should be highlighted here is that coefficient of the regressor in the model is not a parameter of the impact of the ITF on the inflation rate. The effect of ITF can only be estimated through the following method, which compares parameters estimated with data pre- and post-episode of the adoption of the ITF.

Based on that, in order to investigate whether there exists a structural break on trend of inflation rate, the study runs three possible regressions for the distributed-lag model, which are merely distinct in terms of time span, and later compare the parameters from the three regressions. In this case, the regressions use three different datasets: [January 1990 to June 2005 (before ITF in force)]; [July 2005-December 2014 (when ITF in force)] and [January 1990-December 2014 (before and after period)].

The Chow test uses the following ratio:

$$
F \equiv \frac{2 R S S_{R} \& R S S_{U R}(4 k}{4 R S S_{U R}(4) n_{1}+n_{\mathbf{2}} \& 2 k}
$$

where $R S S_{R}$ is the restricted residual sum of square or RSS of regression for the whole period of observation, RSSUR is the unrestricted residual sum of square or sum of RSS of regression for the pre- and post-period of the ITF implementation and $n 1+n 2 \&-2 k$ is the degree of freedom of RSSUR, where $n_{\mathbf{1}}$ and $n_{\mathbf{2}}$ is number of observation in the pre- and post-period of the ITF implementation respectively while $k$ is number of parameters estimated. This F-ratio will be compared to the critical F-value at the chosen significance level.

Null hypothesis of the Chow test is that there is no significant difference in the intercept and the slope coefficient between all three regressions, meaning that there is no structural break across periods. The alternative hypothesis says that the intercept and the slope coefficient in the two regressions using data set of the pre- and post-period of the ITF implementation are significantly different meaning that there is a structural break caused by the adoption of the ITF. The null hypothesis can be rejected if the F-ratio is higher than the critical F-value.

Since the Chow test is performed on a distributedlag model, which in this case is two-lag model, the estimation is perhaps suffering from some drawbacks: (1) There is no clear statistical guide as to what is the maximum length of the lag to be used in the model; (2) Adding more lags may lead to lower degrees of freedom of the model; and (3) Consecutive lags incline to be correlated and induce the multicollinearity problem.

\section{Result and Analysis}

\subsection{Impact Evaluation Analysis: Com- paring Countries}

To begin the impact evaluation analysis, descriptive statistics is provided to identify that the data used are strongly balanced, meaning there is no missing data problem (see Table 6). Additionally, Table 6 also provide the mean, standard deviation, minimum and maximum value of each variable in each group.

Model 1 and 2 are estimated using Ordinary Least Squared (OLS), whereas model 3 is estimated by applying Least Squares Dummy Variable (LSDV). Further, outliers are also already detected and excluded from estimations using the Hadimvo procedure in STATA. There are 46 outliers out of 546 observations, which are Norway $(2007,2008)$, Uruguay (1990-1995), Iceland (2006, 2008), Venezuela $(1990,1993-1998,2003$, 2006), Ecuador (1990-1993, 1997-2002), Mexico (1990, 1997), Singapore (1997), Russia (19901996, 1999), Malaysia (1990, 1992), and Argentina (1990-1993). Heteroskedasticity problem also has been removed by applying heteroskedasticityrobust standard errors in STATA. All regression models identify that there is a negative relationship between implementation of the ITF since year 2001 (interaction variable) and inflation rate (outcome variable), but only model 1 and 2 show significant results (see Table 7).

By comparing the three models, model 2 will be used in impact evaluation analysis for this study. In this model, almost all variable are significant in affecting inflation rate except trade to GDP ratio, which its $\mathrm{p}$-value is greater than $10 \%$. It means that null hypothesis, coefficient of each variable is equal to zero (Ho: Coefficient $=0$ ), can be rejected for case of every independent variable except trade to GDP ratio variable and cannot be rejected for case of trade to GDP ratio variable. For panel data, 
Table 6: Descriptive Statistics for Each Group

\begin{tabular}{|c|c|c|c|c|c|c|c|c|}
\hline \multirow[t]{2}{*}{ Variable } & \multicolumn{4}{|c|}{ Control Group } & \multicolumn{4}{|c|}{ Treatment Group } \\
\hline & Mean & S.D. & Min & Max & Mean & S.D. & Min & Max \\
\hline Inflation Rate & 7.6 & 7.93 & 0.47 & 35 & 22.83 & 138.74 & -4.02 & 2313.97 \\
\hline Broad Money Growth & 14.38 & 13.15 & -10.03 & 83.79 & 19.81 & 58.82 & -50.81 & 1113.27 \\
\hline Government Fiscal Balance & 0.77 & 5.7 & -12.65 & 20.01 & -0.5 & 3.68 & -10.39 & 20.49 \\
\hline Five-Year Central Bank Governor's turnover rate & 0.19 & 0.17 & 0 & 0.6 & 0.21 & 0.27 & 0 & 1.6 \\
\hline Trade to GDP ratio & 63.16 & 25.13 & 29.62 & 142.78 & 68.93 & 77.82 & 10.68 & 394.48 \\
\hline Asian Financial Crisis Period & 0.1 & 0.3 & 0 & 1 & 0.1 & 0.29 & 0 & 1 \\
\hline Global Financial Crisis Period & 0.14 & 0.35 & 0 & 1 & 0.15 & 0.35 & 0 & 1 \\
\hline Country Category & 0.4 & 0.49 & 0 & 1 & 0.24 & 0.43 & 0 & 1 \\
\hline Number of Observation & \multicolumn{4}{|c|}{105} & \multicolumn{4}{|c|}{441} \\
\hline
\end{tabular}

R-squared of this model is moderately high, which is 0.44 . It explains that $44 \%$ of the variance in outcome variable can be explained by independent variables.

The following Table 8 explains the interpretation of causal effect of every coefficient of the independent variable on the dependent variable. The relationship between every independent variable and dependent variable moreover satisfies the hypothetical design previously explained in Table 4.

Three key variables in this study are ITF, postperiod and interaction variables. Coefficient of ITF variable is 3.46 , and it is significant at $1 \%$ significance level. It describes that by holding all variables constant, inflation rate of countries in the treatment group is on average higher by $3.46 \%$ compared to in the control group. As already mentioned previously, it does not explain about the causal effect between ITF implementation and inflation rate. Post-period variable can describe natural changes due to time varying factors, which should be removed to see the pure effect of the treatment. Its coefficient is -1.82 meaning that by holding all variables constant, during post-period (year 2001-2010) inflation rate will naturally fall by $1.82 \%$ on average compared to during pre-period (year 1990-2000). This coefficient is statistically significant at $1 \%$ significance level.

Interaction variable is the main key variable of impact evaluation analysis of this study since it explains about the pure effect of ITF implementation since year 2001 on inflation level (causal effect). The coefficient of this variable is -2.38 meaning that, holding all variable constant, during postperiod after ITF implementation, all countries employing ITF since year 2001 as their monetary policy framework (countries in treatment group) have experienced relatively lower inflation rate by on average $2.38 \%$ compared to countries which do not, and it has happened merely due to ITF implementation as policy intervention from year 2001 to 2010. In a more simple explanation, implementation of ITF since year 2001 will make inflation rate in ITF countries becomes $2.38 \%$ lower than the inflation rate in non-ITF countries. Additionally, this coefficient is also statistically significant at $5 \%$ significance level.

Compared to model 1 , interaction variable in that model has higher size, which is -5.38 , and it is statistically significant at $1 \%$ significance level. However, this model is not used in the analysis in order to avoid omitted variable bias problem, and it has very low R-squared. Result from the fixed effect DiD (model 3) in the study, which can control unobserved characteristics better that model 2 , shows insignificant relationship between the interaction variable and the outcome variable in any significance level although the coefficient sign is negative. However, model 2 is still preferable since model 3 is using LSDV method in condition where the dataset consists of a lot of entities clustered into four classes. This may cause model 3 to have a major problem of having only a few degrees of freedom.

\subsection{Structural Break Analysis: the ef- fect of ITF on Indonesia Inflation Rate}

To conduct this empirical analysis, the Chow test is performed. Prior to that, the Dicky-Fuller test for unit root is executed to convince that inflation rate dataset exerted in this study satisfies the station- 
Table 7: Impact of ITF on Inflation Rate

\begin{tabular}{|c|c|c|c|}
\hline \multirow[t]{2}{*}{ Regressor } & \multicolumn{3}{|c|}{$\begin{array}{c}\text { Dependent Variable } \\
\text { Inflation Rate (\%) }\end{array}$} \\
\hline & Model 1 & Model 2 & Model 3 \\
\hline ITF (implementing $=1$, or otherwise $=0$ ) & $\begin{array}{r}4.60^{* * *} \\
(1.40)\end{array}$ & $\begin{array}{r}3.46^{\star \star *} \\
(1.11)\end{array}$ & $\begin{array}{r}3.85 \\
(1.73)\end{array}$ \\
\hline Post-Period & -0.45 & $-1.82^{\star * *}$ & $\begin{array}{l}-1.95^{*} \\
(0.79)\end{array}$ \\
\hline $\begin{array}{l}(\text { year } 2001-2010=1 \text {, year } 1990-2000=0) \\
\text { Interaction Variable }\end{array}$ & $\begin{array}{r}(0.62) \\
-5.38^{\star \star \star} \\
(1.50)\end{array}$ & $\begin{array}{r}(0.55) \\
-2.38^{\star \star} \\
(1.20)\end{array}$ & $\begin{array}{r}(0.79) \\
-2.28 \\
(2.27)\end{array}$ \\
\hline Broad Money Growth (\%) & & $\begin{array}{r}0.31^{* * *} \\
(0.03)\end{array}$ & $\begin{array}{r}0.31^{* * *} \\
(0.03)\end{array}$ \\
\hline Government Fiscal Balance (\%) & & $\begin{array}{r}-0.25 \star \star \star \\
(0.06)\end{array}$ & $\begin{array}{r}-0.25^{\star \star *} \\
(0.01)\end{array}$ \\
\hline $\begin{array}{l}\text { Five-Year Central Bank Governor's } \\
\text { turnover rate }\end{array}$ & & $\begin{array}{r}6.07^{* * *} \\
(1.81)\end{array}$ & $\begin{array}{r}6.38^{*} \\
(246)\end{array}$ \\
\hline Trade to GDP ratio (\%) & & $\begin{array}{r}-0.004 \\
(0.003)\end{array}$ & $\begin{array}{r}0.002 \\
(0.005)\end{array}$ \\
\hline $\begin{array}{l}\text { Asian Financial Crisis Period } \\
(\text { year } 1997-1998=1 \text {, or otherwise }=0 \text { ) }\end{array}$ & & $\begin{array}{r}-1.96^{* *} \\
(0.76)\end{array}$ & $\begin{array}{r}-1.97^{* *} \\
(0.48)\end{array}$ \\
\hline $\begin{array}{l}\text { Global Economic Crisis Period } \\
(\text { year } 2007-2009=1, \text { or otherwise }=0)\end{array}$ & & $\begin{array}{r}2.08^{\star * *} \\
(0.64)\end{array}$ & $\begin{array}{r}2.06^{*} \\
(0.76)\end{array}$ \\
\hline $\begin{array}{l}\text { Country Category } \\
\text { (industrial country }=1 \text { or emeroing market countrv }=0 \text { ) }\end{array}$ & & $\begin{aligned}-1.78 * * * \\
(045)\end{aligned}$ & \\
\hline Fixed Effect & No & No & Yes \\
\hline Intercept & $\begin{array}{r}5.45^{\star \star \star} \\
(0.46)\end{array}$ & $\begin{array}{l}1.71^{\star *} \\
(0.67)\end{array}$ & $\begin{array}{r}0.69 \\
(0.96)\end{array}$ \\
\hline Summary Statistics & & & \\
\hline SER & 6.44 & 5.01 & 4.98 \\
\hline R2 & 0.06 & 0.44 & 0.44 \\
\hline Number of Observation & 500 & 500 & 500 \\
\hline
\end{tabular}

ary condition. Table 9 shows data summary of the inflation rate.

Table 10 displays the result of the Dicky-Fuller test. From the table, it can be seen that t-statistics of coefficient $\delta$ of this model is -3.115 . The negative sign of the coefficient implies the value of $\rho$ is less than one. Furthermore, the t-statistics is significant, even at significance level of $1 \%$, as shown in the table. Therefore, the study rejects the null hypothesis and concludes that the inflation rate dataset is stationary in the first-order.

The results of the Chow test are summarized in Table 11. The F-ratio of Chow test for testing whether there is a structural break in terms of pattern of inflation rate after the policy adoption shows that the ratio, which is 17.92 , is higher than the critical Fvalue of all significance levels proving that structural break does exist. It therefore gives an indication that the ITF implementation has been significantly affecting and altering the pattern of inflation rate in Indonesia.

With aforementioned tests, the study so far concludes that ITF implementation in Indonesia statistically has succeeded in creating structural break, which means that this new monetary framework has altered the pattern of inflation rate trend. The test however still cannot give any information visà-vis the direction of the change resulting from the adoption of ITF, whether the inflation volatility becomes decreasing or increasing, more fluctuated or more stable. Thus, the study further compares the parameters of mean and coefficient of variation (CV) of the inflation rate within two-time span of the period being studied (pre- and post-ITF implementation). The $\mathrm{CV}$ represents the ratio of standard deviation to mean which can explain the degree of variation.

As can be recognized from Table 12, the mean of the inflation rate is decreasing with the implementation of the ITF. The mean of monthly yoy basis in- 
Table 8: Interpretation of Covariates' Coefficients

\begin{tabular}{|c|c|c|}
\hline Variable & Coefficient & Interpretation \\
\hline Broad Money Growth & 0.31 & $\begin{array}{l}\text { Holding all variables constant, } 1 \% \text { increase in broad } \\
\text { money growth will lead to } 0.31 \% \text { increase in inflation } \\
\text { level on average. This variable is significant at } 1 \% \text { sig- } \\
\text { nificance level. }\end{array}$ \\
\hline Government Fiscal Balance & -0.25 & $\begin{array}{l}\text { Holding all variables constant, } 0.25 \% \text { government bud- } \\
\text { get surplus will decrease the inflation rate by on aver- } \\
\text { age } 0.25 \% \text {. This variable is significant at } 1 \% \text { significance } \\
\text { level. }\end{array}$ \\
\hline Five-Year Central Bank Governor's turnover rate & 6.07 & $\begin{array}{l}\text { Holding all variables constant, if five-year central bank } \\
\text { governor's turnover rate increases by } 1 \text {, on average, in- } \\
\text { flation rate will go up by } 6.07 \% \text {. This variable is signifi- } \\
\text { cant at } 1 \% \text { significance level. }\end{array}$ \\
\hline Asian Financial Crisis Period & -1.96 & $\begin{array}{l}\text { Holding all variables constant, during the Asian Financial } \\
\text { Crisis happened in year 1997-1998, on average inflation } \\
\text { rate was lower by } 1.96 \% \text { compared to other years. This } \\
\text { variable is significant at } 5 \% \text { significance level. }\end{array}$ \\
\hline Global Economic Crisis Period & 2.08 & $\begin{array}{l}\text { Holding all variables constant, when the Global Eco- } \\
\text { nomic crisis happened, inflation rate increased by } 2.08 \% \\
\text { on average compared to other years. This variable is sig- } \\
\text { nificant at } 1 \% \text { significance level. }\end{array}$ \\
\hline Country Category & -1.78 & $\begin{array}{l}\text { Holding all variables constant, on average, inflation rate } \\
\text { in industrial countries is less by } 1.78 \% \text { compared to } \\
\text { emerging market countries. This variable is significant } \\
\text { at } 1 \% \text { significance level. }\end{array}$ \\
\hline
\end{tabular}

Table 9: Data Summary of Inflation Rate

\begin{tabular}{lcccccl}
\hline Variable & Number of Obs. & Mean & Std. Dev & Min & Max & Description \\
\hline $\begin{array}{lcccl}\text { Inflation Rate } \\
\text { Time }\end{array}$ & 300 & 10.44 & 12.41 & -1.1 & 82.4 & $\begin{array}{l}\text { Percentage change of Consumer Price Index yoy basis; } \\
\text { in monthly data }\end{array}$ \\
& 300 & & & From January 1990 to December 2014; in monthly data \\
\hline
\end{tabular}

flation rate has dropped by around five percentage points (from $12.42 \%$ to $7.22 \%$ ) during post-ITF implementation. This means that the rate of the price level has been decreasing since the ITF adoption. In other words, inflation rate tends to be lower than the rate before the introduction of the ITF as the monetary framework. In addition to that, with regard to the variation of inflation rate (volatility), the study indicates a weakening trend of $\mathrm{CV}$, from 1.22 to 0.42 , meaning that inflation rate in Indonesia has become more stable or less fluctuated with the ITF implementation. If the study assumes the episode of the Asian Financial Crisis 1997/1998 never happened by omitting inflation rate data for those periods out from the dataset, the monthly yoy basis inflation rate on average is still decreasing, from $8.01 \%$ to $7.22 \%$ during post-ITF adoption.

By setting the price index as an anchor, stopping the crawling band exchange rate system and switching base money targeting as the framework of monetary policy to inflation rate targeting, Bank Indonesia successfully manages to increase the certainty of price level movements in the economy. The direction and main objective of monetary policy is now clearer, guiding public expectation of the inflation rate to the path where the inflation rate has been aimed by Bank Indonesia. Indeed, the uncertainty caused by the fluctuation of the price level now is reducing, which enables public to forecast the inflation rate more accurate. These conditions in the end will boost the credibility of Bank Indonesia as a monetary authority in Indonesia, and makes inflation rate to be relatively lower and more stable.

For visual analysis, Figure 2 demonstrates that the movement of the inflation rate is getting closer to the target midpoint in recent years after ITF implementation. Some moderate fluctuations can be identified in period of post-ITF implementation, which are more caused by external factors, which 
Table 10: Dickey-Fuller Test for Unit Root

\begin{tabular}{ccccc}
\hline \multicolumn{5}{l}{ Number of observation $=298$} \\
\hline Coefficient & t-statistics & $1 \%$ critical value & $5 \%$ critical value & $10 \%$ critical value \\
$\delta$ & -3.115 & -2.580 & -1.950 & -1.620 \\
\hline
\end{tabular}

Table 11: Result of The Chow Test of Distributed-lag Model for ITF Implementation

\begin{tabular}{|c|c|c|c|c|c|c|c|c|}
\hline \multirow[b]{2}{*}{$\begin{array}{l}\text { Time } \\
\text { Period }\end{array}$} & \multirow[t]{2}{*}{ Statistics } & \multirow[b]{2}{*}{$\begin{array}{c}\text { Number of } \\
\text { Obs. }\end{array}$} & \multirow[b]{2}{*}{$\begin{array}{l}\text { Number of } \\
\text { Parameters }\end{array}$} & \multicolumn{3}{|c|}{ Chow Test } & \multirow[b]{2}{*}{ F-ratio } & \multirow[b]{2}{*}{$\begin{array}{l}\text { Critical } \\
\text { F-value }\end{array}$} \\
\hline & & & & RSSR & RSSUR & $\begin{array}{c}\text { df of } \\
\text { RSSUR }\end{array}$ & & \\
\hline January 1990 to June 2005 (Pre) & 581.75 & 184 & 3 & & & & & $\begin{array}{l}\text { For } 1 \% \\
3.85\end{array}$ \\
\hline July 2005 to December 2014 (Post) & 188.45 & 114 & 3 & 911.99 & 770.2 & 292 & 17.92 & $\begin{array}{l}\text { For } 5 \% \\
2.64\end{array}$ \\
\hline January 1990 to December 2014 & 911.99 & 297 & 3 & & & & & $\begin{array}{l}\text { For } 10 \% \\
2.1\end{array}$ \\
\hline
\end{tabular}

are the Global Economic Crisis in year 2008 and weakening of Rupiah due to the Fed's tapering issue in end of year 2013 to beginning of 2014.

This Chow test unfortunately cannot give any concrete proof on the impact of ITF adoption on durability of Indonesia's economy during the economic crisis period, whether the ITF implementation directly or indirectly may help the economy in dealing and further escaping from the crisis. In addition to that, as previously explained in Figure 2, Indonesia still experienced the impact of shock coming in from the outside of an economy on the price level, even though the impact was not really that massive. The inflation rate of post-ITF implementation in general still can be said to be relatively lower and less volatile. This finding gives a glimpse that ITF may indirectly help the economy in overcoming the economic crisis.

In dealing with shocks on the economy, sole monetary policy is only able to perform demand management to curb the effect of the shock on the demand side of inflation (demand-pull inflation), not on the supply side (cost-push inflation). Many people hence argue the effectiveness of monetary instrument alone in overcoming the economic crisis. ITF implementation in fact may help bridging this gap in managing inflation. By anchoring the inflation rate to a certain level, the government may use its role as the highest economy's regulator to exert policies to deal with inflation coming from the supply side. It indeed shall boost the synchronization between monetary and fiscal policies, which in some cases can be not in line, in keeping the price level relatively low and stable in order to sustain economic growth and development and further to escape from the economic crisis.

In case of Indonesia, the adoption of ITF is followed by the establishment of the Inflation Targeting, Monitoring and Control Team in year 2005 as coordinating agency between Bank Indonesia and the government, and in the end of the day it leads to harmonize these two economic policies in managing inflation rate even during the episode of economic crisis. By considering this concept, ITF indirectly might be effective and used as one of pivotal policies for monetary authority and government in hindering and further coping the economic crisis.

\section{Conclusion}

High inflation is an economic phenomenon, which most countries shun experiencing it due to its negative effect on economic performance. Ample countries utilize monetary policy to manage inflation to keep low and less volatile. Monetary instruments only, is unfortunately cannot fully control the price level since it merely prevails over the demand-pull inflation, not the cost-push inflation. Additionally, monetary policy targeting base money or the exchange rate as the ultimate objective is proven to fail in managing the price level and not quiteresponsive during the event of an economic crisis. Thus, in the last 2 decades, 28 monetary authorities have been starting to employ ITF as 
Table 12: Mean and Coefficient Variation of Inflation Rate

\begin{tabular}{lrrr}
\hline Period & Mean & Std. Deviation & CV \\
\hline Pre-ITF implementation & 12.42 & 15.16 & 1.22 \\
Post-ITF implementation & 7.22 & 3.78 & 0.52 \\
\hline
\end{tabular}

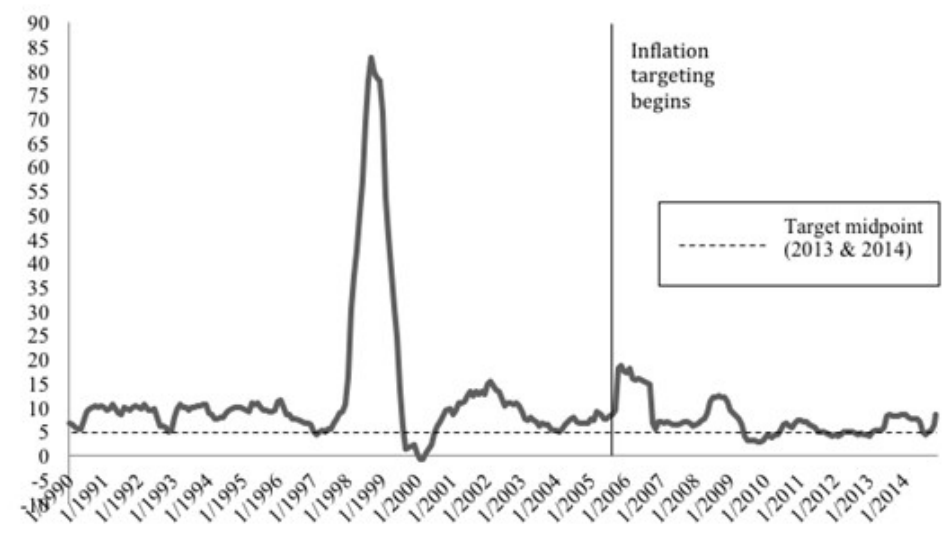

Figure 2: Indonesia's Inflation Rate (\%)

Source: IMF's International Financial Statistics (illustrated by author)

their best practice of monetary policy, targeting relatively low and stable inflation rate.

By conducting impact evaluation analysis on ITF implementation since year 2001 in 5 countries, with 21 selected non-ITF countries as a control group, for period of year 1990 to 2010, it can be concluded that ITF as policy intervention is statistically significant in reducing inflation rate within that period. On average, five countries adopting ITF since year 2001 experienced reduction in inflation rate by $2.38 \%$ lower compared to countries that do not. Based on this finding, this study indicates that the ITF is statistically proven to be a better framework of monetary policy in keeping price level low and stable.

In the case of Indonesia, inflation rate on average has been reducing after the adoption of the ITF in the year 2005. The Chow test on a distributedlag model for the inflation rate within period January 1990-December 2014 has been conducted and the result of the test is supporting that notion, meaning that there is a significant structural break in the pattern of inflation rate trend. The inflation rate furthermore also becomes less volatile after ITF has been implemented, implicating that the price level is now becoming more stable.

\section{References}

[1] Bernanke, BS, Laubach, T, Mishkin, FS, \& Posen, AS 1999, Inflation Targeting: Lessons from the International Experience, Princeton University Press, Princeton.

[2] BI n.d., The Inflation Target. Bank Indonesia. Available from: $\quad<$ http://www.bi.go.id/en/moneter/inflasi/bi-daninflasi/Contents/Penetapan.aspx>. [23 February 2015]

[3] BI n.d., Monetary Policy Framework in Indonesia. "Bank Indonesia. Available from: $<$ http://www.bi.go.id/en/moneter/kerangkakebijakan/Contents/Mengapa.aspx>. [23 February 2015].

[4] Brito, RD 2011, 'Inflation Targeting did Make a Difference in Industrial Countries' Inflation and Output Growth', Insper Working Paper WPE: 272/2012. Insper-Instituto de Ensino e Pesquisa [Institute of Education and Research, Brazil. Available from: <http://www.insper.edu.br/en/wpcontent/uploads/2013/12/2012_wpe272.pdf>. [21 February 2015]

[5] Daboussi, OM 2014, 'Economic Performance and Inflation Targeting in Developing Economies', Journal of World Economic Research, vol. 3, no. 1, pp. 1-7. Available from:<http://article.sciencepublishinggroup.com/pdf/10.11648.j.jwer.20140 301.11.pdf>. [21 February 2015]. doi: $10.11648 / j . j w e r .20140301 .11$

[6] Debelle, G, Masson, P, Savastano, M, \& Sharma S 1998, 'Inflation Targeting as a Framework for Monetary Policy', Economic Issues, no. 15. International Monetary Fund. Available

from:<http://www.imf.org/external/pubs/ft/issues/issues15/index. $\mathrm{htm}>$.[21February2015].

[7] Gemayel, ER, Jahan, S, \& Peter, A 2011, 'What Can Low-Income Countries Expect from Adopting Inflation Targeting?', IMF Working Paper WP/11/276. International Monetary Fund, Washington. Available from: 
<http://www.imf.org/external/pubs/ft/wp/2011/wp11276.pdf>[21 February 2015].

[8] Gujarati, DN 2003, Basic Econometrics, 4th ed., McGrawHill, Singapore.

[9] IMF 2005, 'Does Inflation Targeting Work in Emerging Markets?', World Economic Outlook: Building Institutions, chapter IV, pp. 161-186. International Monetary Fund, Washington. Available from: <http://www.imf.org/external/pubs/ft/weo/2005/02/pdf/chapter4.pdf>. [21 February 2015].

[10] Jahan, S 2012, Inflation Targeting: Holding the Line, Finance \& Development, International Monetary Fund. Available from: <http://www.imf.org/external/pubs/ft/fandd/basics/target.htm\#author > 2015]. [21 February

[11] Kasseeah, H, Weng, JMF, \& Moheeput, KP 2011, 'Central Bank Independence: Evidence from Africa', Journal of Emerging Trends in Economics and Management Sciences (JETEMS), vol. 2, no. 4, pp. 325332. Scholarlink Research Institute Journals. Available from:

<http://jetems.scholarlinkresearch.com/articles/Central\%20Bank\%20| ndependence.pdf>. [23 February 2015].

[12] Lin, S \& Ye, H 2007, 'Does Inflation Targeting Really Make a Difference? Evaluating the Treatment Effect of Inflation Targeting in Seven Industrial Countries', Journal of Monetary Economics, vol. 54, no. 8, pp. 2521-2533. Department of Economics, Florida Atlantic University, Florida. Available from:

<http://www.researchgate.net/profile/Shu_Lin17/publication/223279230_Does_inflation_targeting_really_make_a_difference_Evaluating_the_treatment_effect_of inflation_targeting_in_seven_industrial_countries/links/53d188d70cf220632f3b33ad9.pdf

[21 February 2015].

[13] Mishkin, FS 2004, 'Can Inflation Targeting Work in Emerging Market Countries?', NBER Working Paper 10646. National Bureau of Economic Research, Massachusetts. Available from: http://www.nber.org/papers/w10646.pdf>. [21 February 2015].

[14] Mishkin, FS 2007, The Economics of Money, Banking, and Financial Markets, 8th ed., Pearson Education, Boston.

[15] Roger, S 2010, 'Inflation Targeting Turns 20', Finance \& Development, March 2010, vol. 47, no. 1. International Monetary Fund. Available from: <http://www.imf.org/external/pubs/ft/fandd/2010/03/pdf/roger.pdf>. [21 February 2015].

[16] Stock, JH \& Watson, MM 2012, Introduction to Econometrics, 3rd ed., Pearson Education Limited, England.

[17] Willard, LB 2006, 'Does Inflation Targeting Matter? A Reassessment', CEPS Working Paper No. 120. Center for Economic Policy Studies, Princeton University, Princeton. Available from: <https://www. princeton.edu/ceps/workingpapers/120willard.pdf>. [21 February 2015].

[18] Adisucipto.web.id. (2017). Adisucipto.web.id. [online] Available at: http://adisucipto.web.id [Accessed 27 Jul. 2017]. 